(C) The Author(s), 2021. Published by Cambridge University Press on behalf of the Arizona Board of Regents on behalf of the University of Arizona. This is an Open Access article, distributed under the terms of the Creative Commons Attribution licence (http://creativecommons.org/licenses/by/4.0/), which permits unrestricted re-use, distribution, and reproduction in any medium, provided the original work is properly cited.

\title{
HESSEL DE VRIES: RADIOCARBON PIONEER FROM GRONINGEN
}

\author{
Pieter M Grootes ${ }^{1 *(1)} \cdot$ Hans van der Plicht ${ }^{2}$ (D) \\ ${ }^{1}$ Institute for Ecosystem Research, Christian Albrecht University Kiel, Germany and National Dating Laboratory, \\ NTNU, Trondheim, Norway \\ ${ }^{2}$ Center for Isotope Research, University of Groningen, the Netherlands
}

\begin{abstract}
Hessel de Vries contributed to radiocarbon $\left({ }^{14} \mathrm{C}\right)$ dating for only one short decade. Yet, his development of proportional $\mathrm{CO}_{2}$ counting greatly facilitated ${ }^{14} \mathrm{C}$ measurements, improved their reproducibility, and lowered both the amount of carbon needed for a measurement and the ${ }^{14} \mathrm{C}$ detection limit by at least a factor ten. Validating Libby's ${ }^{14} \mathrm{C}$ method by checking its basic assumptions with improved sensitivity, de Vries documented relatively minor violations. Natural variations in atmospheric ${ }^{14} \mathrm{C}$ concentrations, found in tree rings, marked the start of ${ }^{14} \mathrm{C}$ treering calibration. Variable differences in ${ }^{14} \mathrm{C}$ concentration between the atmosphere and aquatic reservoirs revealed reservoir ages, leading to further studies. De Vries applied analogue modeling to gain a better understanding of the influence of cosmogenic ${ }^{14} \mathrm{C}$ production and the global carbon cycle, inclusive $\mathrm{CO}_{2}$ exchange across the air-water boundary, on atmospheric ${ }^{14} \mathrm{C}$ concentrations. In close collaboration with colleagues in archaeology and geology, de Vries documented climate fluctuations and archaeological developments over the last 50,000+ years and placed them on a common ${ }^{14} \mathrm{C}$ time scale.
\end{abstract}

KEYWORDS: ${ }^{14} \mathrm{C}$ variations, de Vries, Groningen, proportional $\mathrm{CO}_{2}$ counter, radiocarbon, time scale.

\section{HESSEL DE VRIES}

Hessel de Vries, born in 1916, was the son of a schoolteacher. He started studying physics at the University of Groningen, the Netherlands, in 1934 and obtained his PhD (cum laude) in 1942. His thesis was in the field of neutron physics, titled "De Resonantieniveaux van Zilver, Zink, Koper en Aluminium voor het Invangen van Neutronen" ("The Resonance Levels of Silver, Zinc, Copper, and Aluminum for Neutron Capture"). He continued at the University of Groningen as a lecturer and, later, in 1954 as full professor in biophysics. His research interest shifted to the biophysics of the sensory organs (vision, hearing, and smell). As is clear in his 1943 paper "The Quantum Character of Light and its Bearing upon Threshold of Vision, the Differential Sensitivity and Visual Acuity of the Eye," de Vries (1943) sought to understand the basic physics governing the world around and in us. He hypothesized that the thermal motion of molecules in the eye may supply the extra energy needed by small light quanta to pass the energy threshold for registration. He studied color vision, measuring the sensitivity curves for blue, green, and red, and tested his hypothesis of the effects of temperature on vision with test subjects placed in a transformer vessel with hot water, kept at the right temperature with Bunsen burners (de Waard 1960). De Vries also investigated functions of the ear with Jan Willem Kuiper (PhD 1956, "The Microphonic Effect of the Lateral Line Organ: a Study on the Biophysics and the Function of the Lateral Line Organ of Acerina cernua L.") and the sense of smell with Minze Stuiver (PhD 1953-1958, "The Biophysics of the Sense of Smell"), work that is summarized in "Physical Aspects of the Sense Organs" (de Vries 1956a). De Vries was keenly interested in new insights that nuclear physics might provide as evident in his book Kernen der Atomen (Atomic Nuclei) where he presents principles and applications of nuclear physics for the educated Dutch layperson (de Vries 1950).

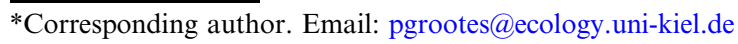




\section{Chicago Tests and the Start of Groningen Radiocarbon}

The novel idea of radiocarbon dating, developed by the nuclear chemist Libby in the 1940s (Libby 1955), needed validation by measuring samples of "known" age selected in close collaboration with colleagues in archaeology, geology, and oceanography. This made for a truly multidisciplinary and international start of radiocarbon research. One of the contributors of test samples was A.E. van Giffen, director of the Biological-Archaeological Institute (BAI) of the University of Groningen, who supplied samples C-621, 623, and 627 (Libby 1955: 89). Van Giffen had excavated wooden posts ascribed to the early St Walburg church in Groningen and Libby's age for the sample, C-621: $2222 \pm 200$ years, was highly exciting because of a surprisingly old date for a Christian church in the Groningen area. Van Giffen thus sought a second opinion and contacted in 1950 his colleague, physicist Hessel de Vries who had worked with proportional counters (de Vries 1946). Although de Vries was immersed in biophysical research, van Giffen persuaded him to develop radiocarbon dating in Groningen.

In their evaluation of potential ${ }^{14} \mathrm{C}$ measurement techniques, Libby and co-workers had considered proportional counting (instead of Geiger counting) and the use of samplederived $\mathrm{CO}_{2}$ as counting gas. However, they had rejected $\mathrm{CO}_{2}$ counting in favor of a modified version of the familiar screen-wall Geiger counter of Libby's dissertation. The sample carbon was painted on the inside wall of a cylinder placed concentrically inside the counter (Anderson 1949; Anderson and Levi 1952). The two arguments against proportional $\mathrm{CO}_{2}$ counting were that $\mathrm{CO}_{2}$ appeared to be a poor counting gas and that high electronic amplifier gains were required to process the small pulses in the proportional counting mode (Anderson 1949). However, de Vries did not see a fundamental physical reason $\mathrm{CO}_{2}$ would not work as a counting gas and in 1950 hired G.W. (Eddy) Barendsen as a $\mathrm{PhD}$ student to develop radiocarbon dating in Groningen. With help from the group for quantitative analysis of the laboratory for organic chemistry, this led to the production of $\mathrm{CO}_{2}$ that performed well as a counting gas. The secret turned out to be the extreme purity of the $\mathrm{CO}_{2}$. This gas performed even better in a proportional mode than in the Geiger mode. Reliable amplification of the proportional pulses was made possible by electronics built by $\mathrm{PhD}$ student Hendrik de Waard, an electronics wizard (de Vries and Barendsen 1952) who later played an essential role in the continuation of the ${ }^{14} \mathrm{C}$ laboratory. They announced the viability of the $\mathrm{CO}_{2}$ proportional counter as an alternative to the Libby counter in a letter to Physica in August 1952. In July of the next year, they described and discussed in detail "Radio-carbon dating by a proportional counter filled with carbon dioxide" (de Vries and Barendsen 1953). Their counter system had a background comparable to the Libby counters and gave similar count rates for a modern carbon gas sample with $1 \mathrm{~g}$ of carbon, about one-tenth of the Libby sample size. The paper described the counter design (Figure 1) and operation as well as the production of pure sample $\mathrm{CO}_{2}$. It also discussed factors affecting the counter background and the accuracy of the results and gave hints at future improvements.

De Vries and his co-workers had already dated 30 samples. Those early results, reported in Nature (de Vries and Barendsen, 1954), included van Giffen's St Walburg Church sample that started the Groningen radiocarbon project. Ten measurements of wood from different parts of the presumed medieval St Walburg church post that had undergone different chemical cleaning, gave statistically consistent radiocarbon ages with an average of about $1000 \mathrm{yr}$, making the church medieval again. Control measurements of the sample in 
(a)

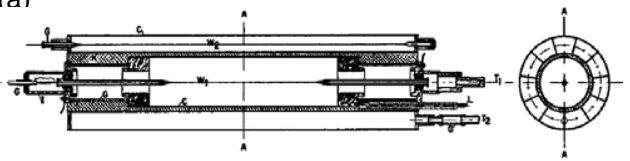

(b)

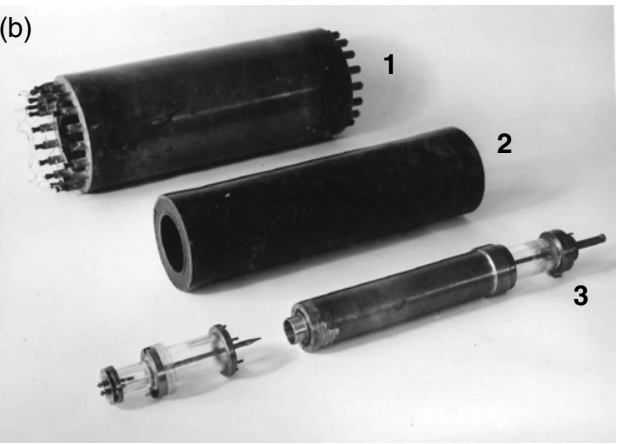

Figure 1 (a) The original Groningen counter design published by de Vries and Barendsen (1953), (b) the elements of the counter in 1(a): 1) multi-wire Geiger-Müller (GM) anti-coincidence ring counter, 2) ceresine cylinder providing insulation between the GM ring-counter and the proportional counter, 3) proportional counter and end pieces.

Heidelberg and London were in agreement statistically. Repeats at Libby's Chicago laboratory however yielded even higher ages for the original carbon sample and for a new combustion. The discrepancy remained unexplained. For a detailed reconstruction of the history of these dates, see Lanting (1990).

Following the prototype $\mathrm{CO}_{2}$ proportional counting system, Barendsen constructed a multicounter system for routine radiocarbon measurements. The system was to house the first counter plus two more with improved design and different volumes in a common iron shield. Counter construction was done in collaboration with the Physics Laboratory of Philips, Eindhoven. The initial system had been built in a laboratory restroom (after toilet removal, Stuiver 2009). The radiocarbon dating laboratory was housed in a small annex to the physics workshop. Continuing tests of different shielding, anti-coincidence geometries, and a study of radioactive impurities in counter and shielding materials resulted in the design of a 14-ton iron shield housing three proportional $\mathrm{CO}_{2}$ counter systems of $0.3,0.8$, and $2 \mathrm{~L}$ volume. This became the core of the new Groningen Radiocarbon laboratory for dating and isotope research (Figure 2). Barendsen's thesis in September 1955 titled "Ouderdomsbepaling met Radioactive Koolstof" ("Age Determination Using Radioactive Carbon"), described the laboratory and included the design of the counters, their shielding and electronics, counter operation and characteristics, and the preparation method for pure $\mathrm{CO}_{2}$. For modern carbon, the three counters filled with 3 atm. $\mathrm{CO}_{2}$ yielded counting rates of 5.5, 15.9, and 37.2 counts per minute (cpm) with backgrounds of $2.8,1.8$, and $5.6 \mathrm{cpm}$, respectively, which resulted in age ranges of 29,000, 40,000, and 44,000 years for a 48-hr counting period.

After his $\mathrm{PhD}$, Barendsen worked from 1955 to 1956 as research associate at the Yale Geochronometric Laboratory. There he implemented $\mathrm{CO}_{2}$ proportional counting (Barendsen et al. 1957) and also worked on the development of a ${ }^{14} \mathrm{C}$ scintillation counting system. In 1956 , he left the field of radiocarbon dating and started research in the field of radiochemistry at the Radiobiological Institute of the Dutch Organization for Applied Science Research (TNO) in Rijswijk, the Netherlands. 


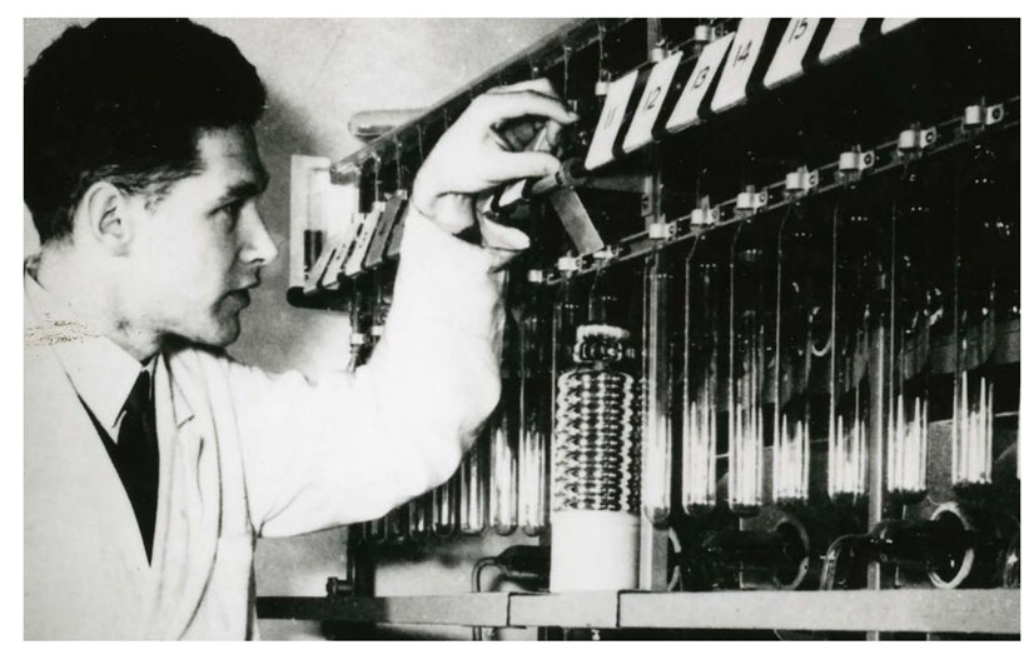

Figure 2 Hessel de Vries at his multi-sample $\mathrm{CO}_{2}$ storage system.

\section{From Elemental Carbon to $\mathrm{CO}_{2}$ in a Growing Radiocarbon Community}

The Libby screen-wall Geiger counter proved to be a workable device. Yet, it required a large amount of sample carbon that had to be laboriously prepared and inserted into the disassembled counter (de Vries and Barendsen 1953). The loading was by no means easy. It required considerable skill and led Jim Arnold to the evaluation that the counter was a "cantankerous device" that might have been developed "in hell" (see Taylor and Bar-Yosef 2014: 279). Moreover, handling the highly absorptive elemental carbon samples in air posed a serious problem of contamination by atmospheric radioactivity. Background problems, probably related to atmospheric nuclear tests in the Pacific and Nevada, were already noticed at Yale during the first part of 1952 (Blau et al. 1953). As a result, there was a general search for alternatives to the screen-wall counter in the early 1950s. The obvious gas to use for several reasons was $\mathrm{CO}_{2}$, but it seemed nobody knew how to make a $\mathrm{CO}_{2}$ sample work as a counting gas. The 1952 and 1953 Groningen reports of a working $\mathrm{CO}_{2}$ proportional counter thus attracted much interest. E H. Willis, who in 1952 started a PhD on the construction of an acetylene proportional counting system in Cambridge, writes in his recollections: "someone had done it!", i.e., found out how to use $\mathrm{CO}_{2}$ as a counting gas (Willis 1996). Willis wrote de Vries and asked for a visit "to learn at first hand how the miracle had been wrought." De Vries welcomed him to Groningen and provided enthusiastic and continuing support to the Cambridge group.

Radiocarbon research had spread out from the Chicago laboratory, but initially contacts between European groups had been limited. In 1954 Hilde Levi, head of the Copenhagen carbon-14 dating laboratory, invited European radiocarbon dating practitioners to Copenhagen for an informal symposium (Godwin 1954). Discussions there were largely technical and concerned solid carbon counting (in use or under construction in Copenhagen, Rome, Trondheim, and Stockholm) as well as gas counters ( $\mathrm{CO}_{2}$ in Groningen and Heidelberg, acetylene in the Royal Institution, the British Museum and Harwell jointly, and Cambridge, and methane in Göteborg). Godwin reports: "It became perfectly clear that gas-counting both by carbon dioxide and by acetylene is more expeditious and somewhat more sensitive than screen-wall counting of elemental carbon, and may be expected to displace the older 
method." The meeting was repeated in 1955 in Cambridge with the participation of a few leading Americans (Levi 1955). By that time nuclear fallout, caused by atmospheric nuclear testing since 1954, was leading to increasing background problems in, and abandonment of, solid carbon counting. New developments in gas counting and liquid scintillation counting were thus eagerly discussed (Levi 1955). At the time, 11 radiocarbon laboratories were in operation or near completion in Europe, 7 in the United States and Canada, and 1 in New Zealand. Discussions of internationally uniform protocols for calculating and reporting of radiocarbon results and of making these results available to a wide community were starting to lay the groundwork for the radiocarbon community of which we now commemorate the 70th anniversary. The "International Conference on Radiocarbon Dating" in Andover in 1956 assembled 53 participants, of which 15 were non-U.S., from physics and a wide range of environmental sciences. The program featured, in addition to sessions on methodology and regional stratigraphic/chronological problems, a session on reservoir and mixing problems and one on major stratigraphic problems. (Johnson et al. 1957). With Revelle, Suess, Craig, Broecker, and Emiliani among the participants, this must have immersed de Vries in the latest discussions on climate, oceanography, the carbon cycle, and their potential interrelationships now and in the past. These are fundamental themes taken up in his research of the late 1950s. By the time of the 1959 carbon-dating conference in Groningen, the regular pattern of Radiocarbon Conferences had been established. Of the 22 laboratories from 12 countries participating, the majority favoured carbon dioxide counting (Godwin 1959).

\section{Research in Groningen: Radiocarbon Measurements}

After initial hesitation, de Vries became interested in the basics of radiocarbon research. Parallel to the construction of the three-counter system de Vries and Barendsen explored how to lower backgrounds and increase modern count rates in order to increase measurement precision and dating range of the counters. Extension of the latter further into the last ice age was of special interest for geologists and palaeobotanists with whom they collaborated.

A background contribution by gamma radiation from the shield had been identified by Kulp and Tryon (1952). Adding a 2-cm layer of lead between counter and anti-coincidence ring led to a substantial reduction of the Groningen counter backgrounds (de Vries and Barendsen 1953, 1954). Detailed analysis of the remaining background indicated a possible contribution by neutrons, generated by cosmic radiation in the shield that passed the anti-coincidence ring undetected. The solar flare of February 23, 1956, provided de Vries with a natural "neutron event" for his background analyses (de Vries, 1956b, 1956c, 1957). Separating background contributions in a constant fraction, probably related to radioactive impurities, and a varying neutron fraction yielded for the latter a barometric pressure dependency of ca. $10 \%$ per $\mathrm{cm} \mathrm{Hg}$, in agreement with that of locally produced neutrons. Placing paraffin wax mixed with 15 weight percent boric acid inside the iron shield reduced the neutron fraction by about a factor seven, allowed for a pressure-corrected, thus more stable background, and extended the range of the large Groningen counter in a two-day counting period to just over 50,000 years (de Vries 1957).

The often-limited amount of carbon available in archaeological samples called for a small efficient counter. In a collaboration between Groningen and Uppsala, two small $0.55 \mathrm{~L}$ counters were constructed and tested jointly in Groningen and Uppsala (de Vries et al. 
1959). Ingrid Olsson, on a scholarship, and Minze Stuiver, leaving his $\mathrm{PhD}$ studies on the sense of smell for a moment, worked on the project. Yet, de Vries was involved to such extent that one Monday morning, as Minze showed up to assemble the cleaned counter parts prepared before the weekend, he found de Vries had already put them together on Sunday. The two counter systems had $85 \%$ effective volume and gave with $0.83 \mathrm{~g}$ of carbon in $48 \mathrm{hr}$ a statistical uncertainty of about 50 years for modern samples and $2-\sigma$ age ranges of 45,800 and 44,500 years for Uppsala and Groningen, respectively. The difference in age range was attributed to the relatively unshielded position of the Groningen counters in a one-story annex. Based on the growing reputation of the Groningen Radiocarbon Laboratory and the importance of large passive shielding for low background counting, de Vries was able to obtain funds for a dedicated underground radiocarbon laboratory, and construction started in 1959.

At the FOM (Fundamenteel Onderzoek der Materie i.e., Fundamental Research of Matter) Institute for Atomic and Molecular Physics in Amsterdam, research on isotope separation using thermal diffusion had started in 1952 after its director J. Kistemaker visited Chicago. A difference between the thermal diffusion coefficients of ${ }^{14} \mathrm{C}^{16} \mathrm{O}$ and ${ }^{12} \mathrm{C}^{18} \mathrm{O}$ in ${ }^{12} \mathrm{C}^{16} \mathrm{O}$ in a Clusius-Dickel thermal diffusion column was reported by A. E. de Vries et al. in 1956. In collaboration with $\mathrm{H}$. de Vries, a system for the enrichment of ${ }^{14} \mathrm{C}$ samples was built in Amsterdam in 1957 and first results and a potential extension of the radiocarbon dating age range to 70,000 years was reported in Science in 1958 (Haring et al. 1958). This thermal diffusion (TD) system was regularly used by de Vries and his successors for very old samples until the mid 1960s.

\section{Research in Groningen: Applications}

Radiocarbon research in Groningen was supported by the Netherlands Organization for Pure Scientific Research (ZWO, now NWO) and many of the samples were selected by an advisory committee of geologists and archaeologists led by I. M. van der Vlerk of the Natural History Museum in Leiden and W. H. (Waldo) Zagwijn, head of Palynology and Stratigraphy at the State Geological Survey (RGD) in Haarlem. An early project of high societal interest concerned relative sea level change on the Dutch coast. The flood disaster of early 1953 had led to the planning of the Delta Project, aimed at future flood protection by the closure of the estuaries in the southwestern Netherlands. The Groningen Radiocarbon Laboratory came just in time to help quantify the timing and rates of relative sea-level changes during the Holocene (de Vries and Barendsen 1954; Barendsen 1955).

De Vries had a broad interest in new applications of nuclear physics techniques, and he did not limit himself to measuring the ${ }^{14} \mathrm{C}$ concentration of the samples submitted. He became actively involved in their provenance and uncertainties and in the interpretation of the results. Radiocarbon offered the possibility of dating stratigraphy and reconstruction of climate and environmental conditions. These are based on pollen, macrofossils and foraminifera, and dating moves them from a relative to an absolute time scale thereby bringing together and integrating fragments of local environmental and glacial/interglacial climatic information from geographically widely scattered sites. Environmental and paleoclimate reconstructions became increasingly part of archaeological research at the BAI, where van Giffen had long been investigating the interplay of local sea level, coastal settlements, and dwelling mounds. When van Giffen was succeeded as director of the BAI in 1954 by the palynologist H. T. (Tjalling) Waterbolk, a close collaboration between archaeology and physics, the 
BAI and the Radiocarbon Laboratory developed (de Vries et al. 1958; de Vries and Waterbolk 1958; Dee and van der Plicht 2021). At the Geological Survey, Zagwijn used palynology and radiocarbon to reconstruct climate fluctuations of the last ice age, and early on challenged the range of de Vries's counters with samples of expected early-glacial and Eemian ages exposed at De Voorst in the Noordoostpolder, pumped dry in 1942 (de Vries et al. 1958). While the Groningen large counter technically enabled de Vries to measure old ages, the ${ }^{14} \mathrm{C}$ concentrations of $2 \%$ modern or less, remaining in samples older than 30,000 years, demanded special measures of purity. De Vries experimented with different acid and alkali extraction protocols and tested the ${ }^{14} \mathrm{C}$ concentrations of different chemical fractions of a sample to bring modern contamination down to $<0.1 \%$. Joining the sampling in the field was very useful for understanding the sample setting and potential for contamination. De Vries developed a good eye for little rootlets in the sampled profiles.

In collaboration with Waterbolk and Zagwijn and their European colleagues, de Vries embarked on a project to date early-glacial climatic and archaeological records across Europe: northwestern Europe-Denmark, Northern Germany, the Netherlands, and England; the Alps-in southern Germany and Austria, and studies in Czechoslovakia and Hungary. Apart from climate information, the samples also provided ages for Upper-Palaeolithic Gravettian settlements in Austria and then Czechoslovakia and the Aurignacian in Austria and Hungary. With a common Groningen radiocarbon age, de Vries (1958c, 1959b) could now begin a synthesis of profile information in comparison with the partition of the Würm ice age and the Loess chronology, and with the ocean paleotemperature curve of Emiliani (1955).

\section{The De Vries Effect}

Libby had based the radiocarbon dating method on the assumption that the ${ }^{14} \mathrm{C}$ concentration of atmospheric $\mathrm{CO}_{2}$ was globally constant and had been constant for a long time. His initial testing had proven deviations to be less than $10 \%$, roughly validating the assumption. Measurements with improved precision by Suess showed, however, a decrease in atmospheric ${ }^{14} \mathrm{C}$ concentration of $\sim 1 \%$ over the last $50+$ years attributed to industrial coal combustion (Suess 1955). This is known today as the "Suess effect." When a charred wheat sample of AD 1684 , run by de Vries as a normal system check, showed a higher ${ }^{14} \mathrm{C}$ activity than the 1954 standard, he started a systematic high-precision $(\sigma=0.2 \%)$ study of atmospheric ${ }^{14} \mathrm{C}$ levels using tree rings, absolutely dated by dendrochronology. The results confirmed the fossil carbon related drop of $\sim 1.5 \%$ between 1845 and 1935 reported by Suess (1955) as well as ${ }^{14} \mathrm{C}$ variability in German tree rings back to $1400 \mathrm{AD}$ as reported by Münnich (1957b). De Vries's results documented natural fluctuations in atmospheric ${ }^{14} \mathrm{C}$ concentration of ca. $2 \%$ over the 300 years preceding $\mathrm{AD} 1850$; variability henceforth called the De Vries effect. This proved one basic assumption of radiocarbon dating false at the 1\% level (de Vries 1958a, 1959a). A three-way experiment between Cambridge, Heidelberg, and Copenhagen, warmly endorsed by de Vries, verified these results, using a wedge-shaped segment of a giant sequoia tree which had adorned the entrance lobby to Cambridge Botany. At the Groningen Radiocarbon Conference of 1959, they showed that there had, indeed, been variations of about $1.5 \%$ around the $1859{ }^{14} \mathrm{C}$ value over the 1200 years preceding AD 1850 (Willis et al. 1960).

To evaluate the potential cause(s) of the ${ }^{14} \mathrm{C}$ fluctuations, de Vries (1958a, 1959a) took the freshly published 5-box model of the global carbon cycle of Craig (Craig 1957) and, ever 
(a) CARBON RESERVOIRS

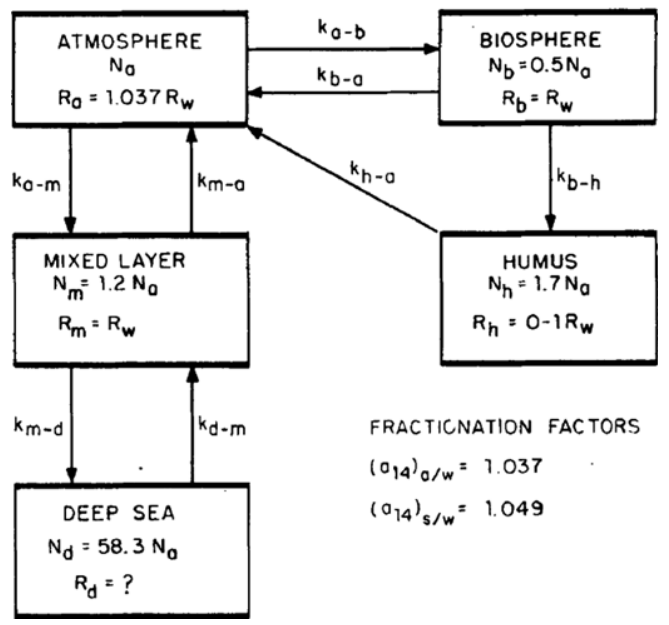

(b)

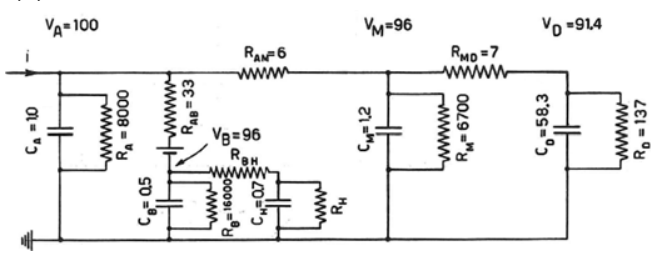

Figure 3 (a) The Craig 5-box model of the global carbon cycle (Craig 1957). (b) The electric analogue of the radiocarbon flux through the Craig model constructed by de Vries to evaluate possible causes of the observed variability in atmospheric ${ }^{14} \mathrm{C}$ concentrations (from Craig 1957 and de Vries 1958a).

the physicist, constructed its electric analogue for modeling experiments: "analogue computing" in the pre-digital era (Figure 3). The circuit identified changes in mixing between surface and deep ocean as a likely cause of the observed atmospheric ${ }^{14} \mathrm{C}$ fluctuations. De Vries also considered variations in ${ }^{14} \mathrm{C}$ production and in atmosphereocean exchange but, based on the knowledge of the time, rejected these as possible causes because their variations appeared too small to explain his observations. Much about cosmogenic isotope production and ocean-atmosphere exchange and mixing still had to be discovered. Independent of the model, he noticed an apparent correlation between climate and ${ }^{14} \mathrm{C}$ over the past 300 years. De Vries' tree-ring results marked the beginning of systematic tree-ring ${ }^{14} \mathrm{C}$ calibration efforts in several laboratories. His modeling introduced the use of varying ${ }^{14} \mathrm{C}$ concentrations in different global carbon reservoirs as boundary conditions for modeling ocean circulation and the global carbon cycle. Much information can be gained from the violation of this basic assumption of the ${ }^{14} \mathrm{C}$ method.

Minze Stuiver described the use of the carbon cycle analogue circuit in his article, "A Random Walk Through Time" (Stuiver 2009). As he submerged in ${ }^{14} \mathrm{C}$ after his $\mathrm{PhD}$ in biophysics (1958), he modeled ${ }^{14} \mathrm{C}$ production rates tied to the sunspot cycle. By carving the sunspot record of the past 400 years in the edge of a metal disk and rotating the disk edge in a light beam, he could modulate the light intensity on a photomultiplier and thus the current input of the carbon cycle analogue circuit. The results, observed on an oscilloscope, turned out to be valid and indicated another cause of natural atmospheric ${ }^{14} \mathrm{C}$ fluctuations: solar activity variations (Stuiver 1961). Minze successfully pursued this lead in his U.S. research.

\section{Bomb ${ }^{14} \mathrm{C}$ and Reservoir Age}

Hessel de Vries observed not only the Suess effect, but also the increase of atmospheric ${ }^{14} \mathrm{C}$ concentrations caused by the atmospheric nuclear tests. In line with his desire to get at the bottom/physics of things and his interest in the carbon cycle, de Vries sampled flesh 
and shells of landsnails, freshwater snails, and marine mussels from the Dutch Waddenzee for measurements of their ${ }^{14} \mathrm{C}$ and ${ }^{13} \mathrm{C}$ content. He found an increase in ${ }^{14} \mathrm{C}$ of $4.3 \%$ in the flesh of land snails from 1953 to 1957 (de Vries 1958b). De Vries linked the increase in snail ${ }^{14} \mathrm{C}$, via plant photosynthesis and plant consumption by the snails, to the change in atmospheric ${ }^{14} \mathrm{C}$. The $4.3 \%$ was in good agreement with a $4.1 \pm 0.5 \%$ increase in atmospheric ${ }^{14} \mathrm{CO}_{2}$ reported by Rafter and Fergusson (1957) for early 1955 to 1957 in New Zealand, but less than the increase observed by Münnich and Vogel (1958) in plant material from Middle-Europe. The ${ }^{14} \mathrm{C}$ in the corresponding snail shell carbonate increased by only $0.9 \%$. No significant enrichment of ${ }^{14} \mathrm{C}$ was observed in flesh or shell of freshwater and marine samples from 1953-1957. This was not unexpected and fitted the delayed response and ${ }^{14} \mathrm{C}$ values of a marine and a freshwater reservoir lower than atmospheric values. The latter was (correctly) ascribed to old carbon in the groundwater influx. Comparison of isotopic values for flesh and carbonate of the three samples gave, however, puzzling results. De Vries applied a ${ }^{14} \mathrm{C}$ fractionation correction twice that of ${ }^{13} \mathrm{C}$ before comparing ${ }^{14} \mathrm{C}$ concentrations (de Vries 1958b). Shell and flesh of the aquatic samples showed, after ${ }^{13} \mathrm{C}$ fractionation correction, fairly similar ${ }^{14} \mathrm{C}$ concentrations but the landsnail carbonate had significantly less ${ }^{14} \mathrm{C}$ than the flesh. Like the variations in atmospheric ${ }^{14} \mathrm{C}$ content with time, this violated another basic assumption of radiocarbon dating. Though unexplained at the time, de Vries's data gave first evidence of the uptake of old soil carbonates by land snails for shell building and of the decoupling of ${ }^{13} \mathrm{C}$ and ${ }^{14} \mathrm{C}$ values when plants or animals exploit carbon sources of different age and origin. These biological influences and the mixing of carbon from different sources and times are still major topics of research in radiocarbon dating today. As de Vries stated at the end of his paper: "The delayed reaction of the ${ }^{14} \mathrm{C}$ concentrations of the aquatic samples and their below-atmospheric values can contribute to the discussion of the global carbon cycle, but this will require the establishment of an international ${ }^{14} \mathrm{C}$ standard to which all measurements can be referred." Indeed, it was decided the next year at the Groningen Radiocarbon Conference that the oxalic acid standard of the U.S. Bureau of Standards should be used as international reference (Godwin 1959).

Hessel de Vries joined an international effort to obtain information about past climate and past atmospheric $\mathrm{CO}_{2}$ content from glaciers and ice sheets while using ${ }^{14} \mathrm{CO}_{2}$ for dating. In 1957 , a field test in Norway extracted $\mathrm{CO}_{2}$ from terminal Storbreen ice, and de Vries produced a first ${ }^{14} \mathrm{C}$ date on ice of $710 \pm 120 \mathrm{yr}$. This was in excellent agreement with estimates by the Norwegian Polar Institute (Coachman et al. 1958). The Arctic Institute Greenland Expedition of 1958 on the Norwegian sealing vessel M/S Rundøy sampled 11 icebergs from outlet glaciers along the Greenland west coast (Scholander et al. 1962). Melting 6 to 16 tons of iceberg yielded about $0.2 \mathrm{~g}$ of carbon. The ${ }^{14} \mathrm{C}$ measurements showed surprisingly low ages with the oldest ice only 3100 years old. Comparison of the ${ }^{14} \mathrm{C}$ results with the ${ }^{18} \mathrm{O}$ content of the icebergs and the Greenland ice sheet by Dansgaard showed in general consistent results and supported the interpretation of ${ }^{18} \mathrm{O}$ content in terms of climate, elevation, and latitude (Scholander et al. 1962). Below-atmospheric $\mathrm{O}_{2}$ concentrations and $\mathrm{CO}_{2}$ values from 0.04 to 0.10 volume percent of the extracted gas indicated dust oxidation as a possible source of extra $\mathrm{CO}_{2}$. In combination with the heroic efforts required to obtain enough sample $\mathrm{CO}_{2}$, this marked the end of ice dating in Groningen. Minze Stuiver revived ${ }^{14} \mathrm{C}$ dating of ice with George Denton at Yale with a successful test of an extraction system at Storglaciaren in Swedish Lapland in the winter of 1966. It would take another 30 years and the sample size reduction with a factor of 1000 brought by AMS to make radiocarbon dating of ice more practical and "reboot" research (e.g., Wilson and Donahue 1990). 
The dating of ice demonstrates that de Vries was flexible in operating his counters. The carbon extracted from the ice must have filled his $0.3 \mathrm{~L}$ counter to somewhat less than 1 instead of the standard 3 atmospheres. This flexibility also enabled him to make a radiocarbon-dating contribution to the solution of the notorious Piltdown skull and jaw hoax (de Vries and Oakley, 1959). Fragments of a mandible and cranial bones "found" in 1912 in the Piltdown gravel pit, supposedly, belonged to a Lower to Middle Pleistocene early human. Though a fraud had been suspected by some from the beginning, it was only in the 1950s that the jawbone was identified as that of a modern orangutan. Two Groningen radiocarbon ages of $500 \pm 100$ years for the mandible (GRO 2204) and $620 \pm 100$ years for the skull (GRO 2203) finalized the proof of the fraud.

By 1959 de Vries was using his ${ }^{14} \mathrm{C}$ counter systems not simply to provide time to archaeology and geology. With the large counter and ${ }^{14} \mathrm{C}$ enrichment combined, he had embarked on a project to study climate and human development during the early part of the last glacial. $\mathrm{He}$ also studied atmospheric ${ }^{14} \mathrm{C}$ variations in the past and their possible causes such as varying cosmogenic ${ }^{14} \mathrm{C}$ production, carbon cycle dynamics in-and exchange betweenatmosphere, ocean and biosphere, climate changes, and the early global bomb ${ }^{14} \mathrm{C}$ "tracer experiment." Construction for his new radiocarbon laboratory was underway and from September 14 to 19 he hosted the international radiocarbon community for a successful meeting (Godwin 1959). Minze Stuiver, who had worked after his $\mathrm{PhD}$ with de Vries on ${ }^{14} \mathrm{C}$, moved to work with Deevey at Yale for a one-year postdoc in late September to take responsibility for ${ }^{14} \mathrm{C}$ measurements upon his return. Sadly, shortly before Christmas 1959, a love affair that de Vries had had for some time with a young laboratory technician came to a tragic end when she broke the relation, and de Vries, unable to make her change her mind, killed her and himself.

\section{Post de Vries: From Groningen Radiocarbon to Center for Isotope Research}

With the sudden death of its dynamic leader Hessel de Vries, the future of Groningen Radiocarbon was in jeopardy. Physics Professor Hendrik de Waard, who had a close interest in the radiocarbon research, took responsibility. Minze received a request to speedily return to Groningen to take over the radiocarbon laboratory, but he was told by the director of the physics laboratory that the new laboratory space under construction would not be available for ${ }^{14} \mathrm{C}$ research (Stuiver 2009). De Waard, together with Waterbolk and Zagwijn and the Dutch radiocarbon community managed to reverse this decision. Yet, Minze decided to continue his ${ }^{14} \mathrm{C}$ and isotope research at Yale and later, in 1969, founded the Quaternary Isotope Laboratory at the University of Washington in Seattle.

De Waard oversaw ${ }^{14} \mathrm{C}$ operations from January 1960 to September 1961 and led the search for a new leader. During this time de Waard initiated as follow-up of the tree-ring work of de Vries and the Cambridge-Heidelberg-Copenhagen group a project with Ingrid Olsson and Åke Vinterbäck of Uppsala University and Bariloche to obtain Patagonian trees for a study of atmospheric ${ }^{14} \mathrm{C}$ variability in the Southern Hemisphere.

J. C. (John) Vogel became the leader of the Groningen laboratory in October 1961. John, originally from South Africa, had done a $\mathrm{PhD}$ on isotope fractionation of carbon between $\mathrm{CO}_{2}$, bicarbonate, and carbonate with Otto Haxel in Heidelberg (Vogel 1959a, 1959b). $\mathrm{He}$ had worked with Karl Otto Münnich on ${ }^{14} \mathrm{C}$ in tree rings looking at the Suess effect, bomb ${ }^{14} \mathrm{C}$, and differences in atmospheric ${ }^{14} \mathrm{C}$ concentration between Europe and Pretoria 
and he had set up a mass spectrometer for carbon and oxygen isotopes (Münnich 1957a; Talma et al. 2012; Kromer et al. 2021). Vogel thus brought a package of Heidelberg skills and interests to the Groningen radiocarbon laboratory. John moved the ${ }^{14} \mathrm{C}$ laboratory into its new underground facilities by late 1962 with simplified $\mathrm{CO}_{2}$ preparation and purification systems and two newly built proportional counters coded LZ and RZ (Vogel and Waterbolk 1967). He undertook, together with Waterbolk, the publication of the ${ }^{14} \mathrm{C}$ results obtained under de Vries and de Waard since Groningen Radiocarbon Dates III. These results were normalized to the newly established international ${ }^{14} \mathrm{C}$ refence of $95 \%$ of the activity of the NBS oxalic-acid standard with $\delta^{13} \mathrm{C}=-19 \%$ and provided a table to convert all earlier de Vries results to the new international standard, which made them accessible as a database for future research (Vogel and Waterbolk 1963). The Groningen reputation for high-quality ${ }^{14} \mathrm{C}$ counters brought Jürgen Freundlich of Cologne and Jacques Evin of Lyon to the laboratory in 1965 for an extended visit and counter construction (Evin et al. 1969; Freundlich et al. 1980: Table 1). Cooperation with Amsterdam on ${ }^{14} \mathrm{C}$ enrichment of palaeolithic and early-glacial samples continued but was halted in the mid-1960s when results showed increasing evidence of contamination (Vogel and Zagwijn 1967).

John obtained in 1962 the first Groningen stable isotope mass spectrometer, the Atlas MAT86 (Massen Analyse Technik, Bremen) to provide in-house measurements of ${ }^{13} \mathrm{C}$ in addition to the existing ${ }^{14} \mathrm{C}$, which by now was considered essential for high-quality ${ }^{14} \mathrm{C}$ studies. The M86 allowed continued investigation of fresh-water carbonates and the $\mathrm{CO}_{2}$-bicarbonate-carbonate system. The M86 was also used for the atmospheric $\mathrm{CO}_{2}$ sampling program that John set up after the one started in Heidelberg by Münnich in 1959. Sample collection began in October 1961 until April 1962 on top of the 30-m Physics Van de Graaff tower. Because of variable fossil fuel influence, sampling was moved in May 1962 out of town to the 80-m television tower at Hoogersmilde. The results documented the local atmospheric ${ }^{14} \mathrm{CO}_{2}$ increase following the resumption of atmospheric nuclear weapons testing in September 1961 (Vogel 1970).

The initiative by de Waard resulted in an expedition to Patagonia, Argentina, in the Southern Hemisphere summer of 1962-1963 and brought Juan Carlos Lerman and several tree slabs, one with rings going back about 1500 years, to Groningen. In continuation of the Heidelberg tree-ring ${ }^{14} \mathrm{C}$ studies, two large counters were dedicated to high-precision ${ }^{14} \mathrm{C}$ measurements of a selection of trees from different latitudes and longitudes in both hemispheres with accompanying ${ }^{13} \mathrm{C}$ correction. The results showed variations in the atmospheric ${ }^{14} \mathrm{C}$ concentration over time that were synchronous and of the same magnitude everywhere. The Patagonian trees contained on average $5.3 \pm 1.3 \%$ less ${ }^{14} \mathrm{C}$ than the European ones back to AD 1400, documenting a ${ }^{14} \mathrm{C}$ offset between the hemispheres and the need for a separate Southern Hemisphere ${ }^{14} \mathrm{C}$ calibration (Lerman et al. 1969, 1970).

John's first PhD student, W.G. (Wim) Mook joined the laboratory in 1962. Wim set up the M86 and systems for ${ }^{13} \mathrm{C}$ and ${ }^{18} \mathrm{O}$ analysis for water and carbonates for his study of the Geochemistry of the Stable Carbon and Oxygen Isotopes of Natural Waters in the Netherlands (Mook 1968). The M86 also provided ${ }^{13} \mathrm{C}$ analyses for the radiocarbon samples and for ${ }^{13} \mathrm{C}$ and ${ }^{18} \mathrm{O}$ isotope research. P. M. (Piet) Grootes did a masters project on isotope fractionation with Wim starting fall 1964 (Grootes et al. 1969; Vogel et al. 1970). John Vogel returned to South Africa in 1967 to establish a new isotope research laboratory at the Counsel 
for Scientific and Industrial Research (CSIR) in Pretoria, and Wim took over the daily running of the laboratory and continued after defending his thesis in 1968.

Plans had been made to bring the Amsterdam ${ }^{14} \mathrm{C}$ enrichment system to Groningen (having less ${ }^{14} \mathrm{C}$ contamination risks) and to add tritium and deuterium analysis to the Groningen capabilities. Two students, D. J. (Dick) Groeneveld and Piet Grootes, joined John Vogel for a year of training in the build-up of his new CSIR laboratory in preparation for a Groningen $\mathrm{PhD}$ starting in 1970 under John and Wim. The Amsterdam ${ }^{14} \mathrm{C}$ enrichment system (a set of fragile 6-m-long glass columns with water-cooled jackets) was rebuilt in the Groningen ${ }^{14} \mathrm{C}$ laboratory and dedicated systems were constructed to produce and handle the large amounts $(\sim 200 \mathrm{~L})$ of $\mathrm{CO}_{2}$ and $\mathrm{CO}$ used for enrichment. The contamination problems were solved and ${ }^{14} \mathrm{C}$ enrichment extended the range of Groningen radiocarbon dating to $\sim 75,000{ }^{14} \mathrm{C}$ years (Grootes et al. 1975). Samples from early-glacial interstadials, continuing the earlier studies, were obtained via Waterbolk and Zagwijn. The 29 enrichment ${ }^{14} \mathrm{C}$ dates yielded a consistent picture of early interstadials ranging in age from 45,500 to 72,300 ${ }^{14}$ C years BP (Grootes 1977, 1978). Dick designed and constructed an electrolytic enrichment system for tritium samples and a proportional counter for tritium dating using ethane (Groeneveld 1977). A copper counter for tritium and a quartz-gold counter for ${ }^{14} \mathrm{C}$ were constructed based on his design and installed in the Barendsen-deVries shield that had been rebuilt in the underground ${ }^{14} \mathrm{C}$ laboratory (Groeneveld 1977; Grootes 1977). Piet went on to work with Minze Stuiver at the Quaternary Isotope Laboratory in Seattle on ${ }^{18} \mathrm{O}$ climate studies in ice cores (1977-1994) (Grootes et al. 1993) and later to ${ }^{14} \mathrm{C}$ AMS at the LeibnizLabor in Kiel, Germany.

Wim broadened the research focus from "Radiocarbon Laboratory" to "Center for Isotope Research" (CIO), increasing the role of isotope-ratio mass spectrometry and of other radioactive isotopes. He applied carbon isotopes in inorganic carbon to find the "age" of groundwater and did basic studies of isotopic fractionation factors. Wim continued the local atmospheric $\mathrm{CO}_{2}$ monitoring with ${ }^{13} \mathrm{C}$ and ${ }^{14} \mathrm{C}$ analysis and teamed up with Charles Keeling and his global $\mathrm{CO}_{2}$ monitoring project at the end of the 1970s. Wim supervised many masters and $\mathrm{PhD}$ students. P. P. (Pieter) Tans ( $\mathrm{PhD}$ in 1978) built a quartz-gold multi-counter $(6.8 \mathrm{~L})$ for high-precision ${ }^{14} \mathrm{C}$ measurements $(1-2 \%$ ) (Tans and Mook 1978) for an extensive study of ${ }^{14} \mathrm{C}$ and ${ }^{13} \mathrm{C}$ in tree rings in relation to atmospheric $\mathrm{CO}_{2}$ (Tans 1978). Pieter continued with $\mathrm{CO}_{2}$ research and went via Scripps (working with Keeling) on to a career at NOAA in Boulder, Colorado, where he led the Carbon Cycle Greenhouse Gases group from 1985 until 2019. C. A. M. (Carl) Brenninkmeijer developed during his $\mathrm{PhD}$ research new and automated methods for hydrogen and oxygen isotope analysis of cellulose (Brenninkmeijer 1983) with application to tree rings and peat deposits for Holocene paleoclimate reconstruction (Brenninkmeijer et al. 1982). He then moved to New Zealand where he did isotope studies of atmospheric CO using ${ }^{14} \mathrm{CO}$ AMS at the DSIR (Department of Scientific and Industrial Research) in Lower Hutt (Brenninkmeijer 1993; Brenninkmeijer et al. 1995). In 1994 Carl joined Paul Crutzen at the Air Chemistry Division of the Max-Planck Institute for Chemistry in Mainz, Germany, where he led the CARIBIC airborne atmospheric sampling program and continued the trace gas isotope study of the oxidative state of the atmosphere.

By 1980, the Center for Isotope Research was in good shape. Thirty years after archaeologist van Giffen asked the physicist Hessel de Vries for help in solving an archaeological question with the tools of physics, the laboratory that de Vries started, had grown, diversified its isotopic 
tool kit and established itself as a national center for isotope research with an international reputation. The application of physics and isotopes to unravel details and dynamics of the global carbon cycle, climate variability, oceanic and atmospheric mixing and exchange, and human development was carried forward under Wim Mook's direction. The work environment at the Physics Department of the University of Groningen with excellent physicists and electronics, mechanical, and glass blower's workshops proved to be enormously beneficial. The de Vries laboratory building, basically a glass house with an underground laboratory, was a very productive site indeed.

Today, the ${ }^{14} \mathrm{C}$ laboratory that de Vries started is part of the Energy and Sustainability Research Institute of the Faculty of Science and Engineering. After 70 years, the laboratory, now housed at its 5th location (including the original restroom "start-up") has diversified a lot and is operating its second AMS (a MICADAS system). The laboratory continues to thrive and contribute to radiocarbon and a wide variety of research questions, including those connected with the Anthropocene.

\section{REFERENCES}

Anderson EC. 1949. Natural radiocarbon [thesis]. Chicago.

Anderson EC, Levi H. 1952. Some problems in radiocarbon dating. Danske Matematisk-fysiske Meddelelser 27(6):3-22.

Barendsen GW. 1955. Ouderdomsbepaling met Radioactive Koolstof [thesis]. Groningen. 88 p.

Barendsen GW, Deevey ES, Gralenski LJ. 1957. Yale natural radiocarbon measurements III. Science 126:908-919.

Blau M, Deevey ES Jr, Gross MS. 1953. Yale natural radiocarbon measurements I. Pyramid Valley, New Zealand and its problems. Science 118:1-6.

Brenninkmeijer CAM. 1983. Deuterium, Oxygen-18 and Carbon-13 in tree rings and peat deposits in relation to climate [ $\mathrm{PhD}$ thesis]. Groningen. $146 \mathrm{p}$.

Brenninkmeijer CAM. 1993. Measurement of the abundance of ${ }^{14} \mathrm{CO}$ in the atmosphere and the ${ }^{13} \mathrm{C} /{ }^{12} \mathrm{C}$ and ${ }^{18} \mathrm{O} /{ }^{16} \mathrm{O}$ ratio of atmospheric $\mathrm{CO}$ with applications in New Zealand and Antarctica. Journal of Geophysical Research 98(D6): 10,595-10,614.

Brenninkmeijer CAM, Lowe DC, Manning MR, Sparks RJ, van Velthoven PFJ. 1995. The ${ }^{13} \mathrm{C}$, ${ }^{14} \mathrm{C}$, and ${ }^{18} \mathrm{O}$ isotopic composition of $\mathrm{CO}, \mathrm{CH}_{4}$, and $\mathrm{CO}_{2}$ in the higher southern latitudes lower stratosphere. Journal of Geophysical Research 100(D12):26,163-26,172.

Brenninkmeijer, CAM, van Geel B, Mook WG. 1982. Variations in the $\mathrm{D} / \mathrm{H}$ and ${ }^{18} \mathrm{O} /{ }^{16} \mathrm{O}$ ratios in cellulose extracted from a peat bog core. Earth and Planetary Science Letters 61:283-290.

Coachman LK, Hemmingsen E, Scholander PF, Enns T, de Vries H. 1958. Gases in glaciers. Science 127:1288-1289.

Craig H. 1957. The natural distribution of radiocarbon and the exchange time of carbon dioxide between atmosphere and sea. Tellus IX:1-17.

de Vries AE, Haring A, Slots W. 1956. Separation of ${ }^{14} \mathrm{C}^{16} \mathrm{O}$ and ${ }^{12} \mathrm{C}^{18} \mathrm{O}$ by thermal diffusion. Physica XXII:247-248.

de Vries H. 1943. The quantum character of light and its bearing upon threshold of vision, the differential sensitivity and visual acuity of the eye. Physics 10:553-564.

de Vries H. 1946. The construction of counter tubes. Physica 11:433-440.

de Vries H. 1950. Kernen der Atomen. Noorduijn's Wetenschappelijke Reeks 34, J.Noorduijn en Zoon N.V. Gorinchem. 250 p.

de Vries H. 1956a. Physical aspects of the sense organs. Progr. in Biophys. and Biophys. Chem. 6:207-264

de Vries H. 1956b. Cosmic radiation during the solar flare of February 23 and its effect on 14C age measurements. Physica 22:357.

de Vries H. 1956c. The contribution of neutrons to the background of counters used for 14C age measurements. Nuclear Physics 1:477-479.

de Vries H. 1957. Further analysis of the neutron component of the background of counters used for $14 \mathrm{C}$ age measurements. Nuclear Physics 3: 65-68.

de Vries H. 1958a. Variation in concentration of Radiocarbon with time and location on earth. Proceedings of the KNAW (Royal Dutch Academy of Sciences) B61:1-9.

de Vries H. 1958b. Atomic bomb effect: variation of Radiocarbon in plants, shells, and snails in the past 4 years. Science 128:250-251.

de Vries H. 1958c Radiocarbon dates for upper Eem and Würm-interstadial samples. Eiszeitalter und Gegenwart 9:10-17.

de Vries H. 1959a. Variation in concentration of radiocarbon with time and location on 
Earth. In: Abelson PH, editor. Research in Geochemistry. New York: John Wiley \& Sons. p. 180-189.

de Vries H. 1959b. Radiocarbon dating of the fossil soils at Ober Fellabrun. Proceedings of the KNAW (Royal Dutch Academy of Sciences) B62:84-91.

de Vries H, Barendsen GW. 1952. A new technique for the measurement of age by radiocarbon. Physica 18:652.

de Vries H, Barendsen GW. 1953. Radiocarbon dating by a proportional counter filled with carbon dioxide. Physica 19:987-1003.

de Vries H, Barendsen GW. 1954. Measurements of age by the carbon-14 technique. Nature 174: 1138-1141.

de Vries H, Barendsen GW, Waterbolk HT. 1958. Groningen radiocarbon dates II. Science 127: 129-137.

de Vries H, Oakley KP. 1959. Radiocarbon dating of the Piltdown skull and jaw. Nature 184:224-226.

de Vries H, Stuiver M, Olsson I. 1959. A proportional counter for low level counting with high efficiency. Nuclear Instruments and Methods 5:111-114.

de Vries H, Waterbolk HT. 1958. Groningen radiocarbon dates III. Science 128:1550-1556.

de Waard H. 1960. Hessel de Vries, physicist and biophysicist. Science 131:1720-1721.

Dee MW, van der Plicht J. 2021. Isotopen in de archeologie-verleden, heden en toekomst. Paleoaktueel 31. In Dutch.

Emiliani C. 1955. Pleistocene temperatures. Journal of Geology 63:538-578.

Evin J, Longin R, Pachiaudi Ch. 1969. Lyon natural radiocarbon measurements I. Radiocarbon 11:112-117.

Freundlich JC, Schwabedissen H, Wendt WE. 1980. Köln radiocarbon measurements II. Radiocarbon 22:68-81.

Godwin H. 1954. Carbon-14 dating. Symposium in Copenhagen. Nature 174:868.

Godwin H. 1959. Carbon-Dating Conference at Groningen. Nature 184:1365-1366.

Groeneveld DJ. 1977. Tritium analysis of environmental water [thesis]. Groningen. $131 \mathrm{p}$.

Grootes PM, Mook WG, Vogel JC. 1969. Isotopic fractionation between gaseous and condensed carbon dioxide. Z. Physik 221:257-273.

Grootes PM, Mook WG, Vogel JC, de Vries AE, Haring A, Kistemaker J. 1975. Enrichment of radiocarbon for dating samples up to 75,000 years. Z. Naturforschung 30a:1-14.

Grootes PM. 1977. Thermal diffusion isotopic enrichment and radiocarbon dating beyond 50,000 years BP [thesis]. Groningen. 221 p.

Grootes PM. 1978. Carbon-14 time scale extended: comparison of chronologies. Science 200:11-15.

Grootes PM, Stuiver M, White JWC, Johnsen S, Jouzel J. 1993. Comparison of oxygen isotope records from the GISP2 and GRIP Greenland ice cores. Nature 366:552-554.
Haring A, de Vries AE, de Vries H. 1958. Radiocarbon dating up to 70,000 years by isotopic enrichment. Science 128:472-473.

Johnson F, Arnold JR, Foster Flint R. 1957. Radiocarbon dating. Science 125:240-242.

Kromer B, Levin I, Lindauer S, Jähne B, Münnich M, Platt U, Schlosser P. 2021. Karl Otto Münnich (1925-2003): in memoriam. Radiocarbon: 1-5. doi: 10.1017/RDC.2021.38.

Kulp JL, Tryon LE. 1952. Extension of the carbon 14 age method. Review of Scientific Instruments 23:296-297.

Lanting JN. 1990. De ouderdom van de gebouwen onder de St. Walburg en Martnikerk. In: Boersma JW, van den Broek JFJ, Offerman GJD, editors. Groningen 1040. In Dutch.

Lerman JC, Mook WG, Vogel JC, de Waard H. 1969. Carbon-14 in Patagonian tree rings. Science 165:1123-1125.

Lerman, JC, Mook WG, Vogel JC. 1970. C-14 in tree rings from different localities. In: Olsson IU, editor. Radiocarbon variations and absolute chronology, Nobel symposium, 12th, Proc. New York: John Wiley \& Sons. p. 275-301.

Levi H. 1955. Radiocarbon Dating, Conference in Cambridge. Nature 176:727-728.

Libby WF. 1955. Radiocarbon dating. 2nd ed. University of Chicago Press. 175 p.

Mook WG. 1968. Geochemistry of the stable carbon and oxygen isotopes of natural waters in the Netherlands [thesis]. Groningen. $157 \mathrm{p}$.

Münnich KO. 1957a. Thesis. Heidelberg. 45 p.

Münnich KO. 1957b. Heidelberg natural radiocarbon measurements I. Science 126:194-199.

Münnich KO, Vogel JC. 1958. Durch Atomexplosionen erzeugter Radiokohlenstoff in der Atmosphäre. Die Naturwissenschaften 45(14): 327-329.

Rafter TA, Fergusson GJ. 1957. "Atom Bomb Effect" - recent increase of carbon-14 content of the atmosphere and biosphere. Science 126:557-558.

Scholander PF, de Vries H, Dansgaard W, Coachman LK, Nutt DC, Hemmingsen E. 1962. Radiocarbon age and oxygen-18 content of Greenland icebergs. Meddelelser om Grønland, Bd 165(1):1-26.

Stuiver M. 1958. The biophysics of the sense of smell [thesis]. Groningen.

Stuiver M. 1961. Variations in radiocarbon concentration and sunspot activity. Journal of Geophysical Research 66:273-276.

Stuiver M. 2009. A random walk through time. Radiocarbon 51:291-300.

Suess HE. 1955. Radiocarbon concentration in modern wood. Science 122:415-417.

Talma S, Visser E, Fuls A, Mook WG, van der Plicht J. 2012. Obituary: Johann Carl Vogel (1932-2012). Radiocarbon 54:xi-xiv.

Tans PP. 1978. Carbon-13 and Carbon-14 in trees and the atmospheric $\mathrm{CO} 2$ increase [thesis]. Groningen. 99 p. 
Tans PP, Mook WG. 1978. Design, construction, and calibration of a high accuracy carbon-14 counting set-up. Radiocarbon 21:22-40.

Taylor RE, Bar-Yosef O. 2014. Radiocarbon dating, an archaeological perspective. 2nd ed. Walnut Creek (CA): Left Coast Press. p. 279.

Vogel JC. 1959a. Isotopentrennfaktoren des Kohlenstoffs im Gleichgewichtssystem Kohlendioxyd-Bikarbonat-Karbonat [thesis]. Heidelberg.

Vogel JC. 1959b. Über den Isotopengehalt des Kohlenstoffs in Süsswasser-Kalkablagerungen. Geochimica et Cosmochimica Acta 16:236-242.

Vogel JC. 1970. Groningen radiocarbon dates IX. Radiocarbon 12:444 471.

Vogel JC, Grootes PM, Mook WG. 1970. Isotopic fractionation between gaseous and dissolved carbon dioxide. Z. Physik 230:225-238.
Vogel JC, Waterbolk HT. 1963. Groningen radiocarbon dates IV. Radiocarbon 5:163-202.

Vogel JC, Waterbolk HT. 1967. Groningen radiocarbon dates VII. Radiocarbon 9:107-155.

Vogel JC, Zagwijn WH. 1967. Groningen radiocarbon dates VI. Radiocarbon 9:63-106.

Willis EH, Tauber H, Münnich KO. 1960. Variations in the atmospheric radiocarbon concentration over the past 1300 years. American Journal of Science Radiocarbon Supplement 2:1-4.

Willis EH. 1996. A worm's eye view of the early days. In: Radiocarbon dating in Cambridge: some personal recollections. History of Quaternary Research in Cambridge. https://www.quaternary. group.cam.ac.uk/history/radiocarbon/.

Wilson AT, Donahue DJ. 1990. AMS carbon-14 dating of ice: progress and future prospects. Nuclear Instruments and Methods B52:473-476. 